37 Underwood MJ, de Bono DP. Increased fibrinolytic activity in the intima of atheromatous coronary arteries: protection at a price? Cardiovasc Res 1993;27:882-5.

38 Clowes AW, Clowes MM, Au YPT, Reidy MA, Belin D Smooth muscle cells express urokinase during mitogenesis and tissue type plasminogen activator during migration in injured rat carotid artery. Circ Res 1990;67:61-7.

39 Clowes AW, Clowes MM, Kirkman TR, Jackson CL, Au YPT, Kenagy R. Heparin inhibits the expression of tissue type plasminomention the expression of tisin injured rat carotid artery. Circ Res 1992;70:1128-36.

40 Zoellner H, Woyta J, Gallicchio M, McGrath K, Hamilton JA. Cytokine regulation of the synthesis of plasminogen activator inhibitor 2 by human vascula endothelial cells: comparison with plasminogen activator inhibit

41 Erickson LA, Fici GJ, Lund JE, Boyle TP, Polites HG, Marotti KR. Development of venous occlusions in mice transgenic for the plasminogen activator inhibitor 1 gene. Nature 1990;346:74-6.

42 Schleef RR, Higgins DL, Pillemer E, Levitt LJ. Bleeding diathesis due to decreased functional activity of type 1 plasminogen activator inhibitor. $\mathcal{f}$ Clin Invest 1989;83: 1747-52.

43 Dieval J, Nguyen G, Gross S, Delobel J, Kruithof EKO. A lifelong bleeding disorder associated with a deficiency of plasminogen activator inhibitor type 1. Blood 1991; 77:528-32.

44 Fay WP, Shapiro AD, Shih JL, Schleef RR, Ginsburg D. Complete deficiency of plasminogen activator inhibitor type 1 due to a frameshift mutation. New Engl $₹$ Med type 1 due to a fram

45 Dawson S, Hamsten A, Wiman B, Henney A, Humphries $S$. Genetic variation at the plasminogen activator S. Genetic variation at the plasminogen activator
inhibitor-1 locus is associated with altered levels of plasminogen activator inhibitor 1 activity. Arterioscler Throm 1991;11:183-90.

\title{
$A$ letter from Europe
}

\section{Cardiovascular pathology in Europe: a new school}

ColleAgues-There is growing concern among pathologists with an interest in cardiovascular diseases. Pathology, which deals with all aspects of disease, but particularly with the essential nature, the causes, and the development of abnormal conditions, encompasses both the basic and clinical sciences. The general lack of interest of pathologists in cardiovascular diseases and the current explosion of interest in molecular biology have led to an undesirable drifting apart of basic and clinical sciences in the crucial arena of cardiovascular diseases. Cardiovascular pathologists, who by virtue of their training, could bridge this gap are struggling to keep their identity as specialists. The present situation in Europe is alarming. The European Society of Cardiology by creating working groups has stimulated research in and integration of basic and clinical sciences. Nonetheless, there is excessive overlap and potential rivalry between groups that share similar basic interests. How, from the viewpoint of pathologists, is interest to be divided between the working groups on developmental anatomy and pathology, cellular biology of the heart, pathogenesis of atherosclerosis, thrombosis and platelets, coronary circulation, myocardial function, and so on?

A group of pathologists who are involved in specialist cardiovascular pathology every day have reconsidered cardiovascular pathology in Europe. They discussed the need to bring together those in Europe with a common interest in cardiovascular pathology and reached a consensus to inaugurate a European School for Cardiovascular Pathology.
The main objective of the school is to identify those with an active interest in cardiovascular pathology and to promote mutual education. The school will provide a platform for liaison between cardiovascular pathologists and adult and paediatric cardiologists and cardiac surgeons. It will promote postgraduate teaching in basic science and clinical medicine, promote and provide support in the implementation of multi-centre studies in cardiovascular pathology, and will coordinate quality control studies of aspects of diagnosis in cardiovascular pathology. Its headquarters are in the Academic Medical Centre, Amsterdam, The Netherlands, and I am its first chairperson.

At a meeting, planned for the spring of 1995, in Amsterdam, there will be state of the art lectures, clinical case presentations, poster sessions, and an open forum to discuss the future of the European School for Cardiovascular Pathology.

If you are interested in registering with the European School for Cardiovascular Pathology-there is no registration fee-write to me for further information. I sign this letter on behalf of Prof Robert $\mathrm{H}$ Anderson, Prof Michael J Davies, Dr Patrick J Gallagher, Prof C James Kirkpatrick, and Prof Gaetano Thiene, founders of the European School for Cardiovascular Pathology.

Department of Cardiovascular Pathology,

ANTON E BECKER

1105 AZ Amsterdam-ZO, The Netherlands 